\title{
First report about the mode of action of combined butafosfan and cyanocobalamin on hepatic metabolism in nonketotic early lactating cows
}

\author{
L. Kreipe, ${ }^{*}$ A. Deniz,† R. M. Bruckmaier, ${ }^{\star}$ and H. A. van Dorland ${ }^{\star 1}$ \\ *Veterinary Physiology, Vetsuisse Faculty, University of Bern, Bremgartenstrasse 109a, 3001 Bern, Switzerland \\ †Bayer Animal Health GmbH, Kaiser-Wilhelm-Allee 50, 51373 Leverkusen, Germany
}

\begin{abstract}
The primary aim was to investigate the effect of combined butafosfan and cyanocobalamin on liver metabolism in early lactating cows through mRNA expression measurements of genes encoding 31 enzymes and transport proteins of major metabolic processes in the liver using 16 multiparous early lactating dairy cows. The treatments included i.v. injection of $10 \mathrm{~mL} / 100 \mathrm{~kg}$ of body weight combined butafosfan and cyanocobalamin ( $\mathrm{TG}, \mathrm{n}=8$ ) on $3 \mathrm{~d}$ consecutively at $25 \pm 3 \mathrm{~d}$ in milk or injection with physiological saline solution similarly applied ( $\mathrm{CG}, \mathrm{n}=8)$. Results include a higher daily milk production for TG cows $(41.1 \pm 0.9 \mathrm{~kg}$, mean \pm SEM) compared with CG cows $(39.5 \pm 0.7 \mathrm{~kg})$. In plasma, the concentration of inorganic phosphorus was lower in the TG cows $(1.25 \pm 0.08 \mathrm{mmol} / \mathrm{L})$ after the treatment than in the $\mathrm{CG}$ cows $(1.33 \pm 0.07 \mathrm{mmol} / \mathrm{L})$. The plasma $\beta$-hydroxybutyrate concentration was 0.65 $\pm 0.13 \mathrm{mmol} / \mathrm{L}$ for all cows before the treatment, and remained unaffected post treatment. The unique result was that in the liver, the mRNA abundance of acylcoenzyme A synthetase long-chain family member 1, involved in fatty acid oxidation and biosynthesis, was lower across time points after the treatment for TG compared with CG cows $(17.5 \pm 0.15$ versus $18.1 \pm$ 0.24 cycle threshold, $\log _{2}$, respectively). In conclusion, certain effects of combined butafosfan and cyanocobalamin were observed on mRNA abundance of a gene in the liver of nonketotic early lactating cows.
\end{abstract}

Key words: liver, gene expression, butafosfan, cyanocobalamin

\section{INTRODUCTION}

The high-yielding dairy cow is struggling with a challenging metabolic imbalance during the periparturient period (van Knegsel et al., 2005). This is characterized by a negative energy balance, observed as low blood glucose and high mobilization of body fat. During this period, the liver plays a central role, as it takes up

Received December 10, 2010.

Accepted June 1, 2011.

${ }^{1}$ Corresponding author: anette.vandorland@physio.unibe.ch the circulating fatty acids and oxidizes them to yield energy in the tricarboxylic acid (TCA) cycle, as well as through synthesis of ketone bodies as an alternative energy source. In excess, fatty acids may accumulate in the liver causing fatty liver, and may increase ketogenesis up to the development of clinical ketosis that causes decreased performance and welfare in dairy cows. In the treatment of ketosis, the use of combined butafosfan and cyanocobalamin solution, commercially available as Catosal (Bayer Animal Health GmbH, Leverkusen, Germany), has been well acknowledged for over $50 \mathrm{yr}$. In addition, several studies (Flasshoff, 1974; Simon, 1990; Larscheid, 1994) show evidence of an improved immune status during treatment with combined butafosfan and cyanocobalamin, and others studies (Delport et al., 2006; Fürll et al., 2006; Sarasola et al., 2008) confirm the efficacy and safety of this combination for subclinical and secondary ketosis. In a recent study, Fürll et al. (2010) concluded that multiple injections of Catosal during the close-up period have a beneficial effect on the metabolism of periparturient dairy cows. But, the exact mode of action of Catosal on metabolism in the early lactating dairy cow is not yet known.

Cyanocobalamin is the synthetic form of vitamin $B_{12}$. Methylmalonyl-coenzyme A (CoA) mutase, a mitochondrial enzyme, involved in the conversion of propionate to succinyl-CoA, which enters in the TCA cycle, is an important gluconeogenic substrate (Kennedy et al., 1992; Taoka et al., 1994), and is vitamin $\mathrm{B}_{12}$-dependent. An insufficient supply of vitamin $\mathrm{B}_{12}$, especially in early lactation, could possibly lead to decreased function of methylmalonyl-CoA mutase, and hinder energy production from propionate, which results in a less active TCA cycle, potentially decreasing gluconeogenesis. A less active TCA cycle would lead to a buildup of acetylCoA derived from fatty acid $\beta$-oxidation, which would alternatively be used for ketone body synthesis, leading to enhanced ketogenesis in the animal. An insufficient supply of vitamin $\mathrm{B}_{12}$ may interfere with folate metabolism, folic acid being essential for formation of the primary intracellular methylating agent (Bailey and Gregory, 1999). 
The second substance in Catosal is butafosfan, which is an organic phosphorus compound used as a phosphorus source for the animal. In dairy cattle, the phosphorus content of liver tissue decreased in early lactation (Grünberg et al., 2009). Phosphorus plays an important role in hepatic carbohydrate metabolism, in which all intermediates in the gluconeogenic pathway must be phosphorylated. Hence, the rates of gluconeogenesis and glycolysis are regulated by phosphorus availability (Berg et al., 2006). Apart from that, phosphorus is an important component of nucleic acids, and adenosine triphosphate, and adenosine monophosphate (Cunningham, 2002), thereby implicated in energy metabolism.

Although both cyanocobalamin and butafosfan may directly affect certain metabolic components and pathways, it is assumed that their indirect effect on hepatic metabolism may be widespread. Therefore, in the present study, a wide range of enzymes and transporters involved in metabolic pathways in the liver (e.g., gluconeogenesis, ureagenesis, ketogenesis, TCA cycle, fatty acid $\beta$-oxidation, and AA synthesis) were evaluated through mRNA abundance of genes encoding key variables involved. Hepatic gene expression data were used to investigate the effect of combined butafosfan and cyanocobalamin, because a more complete image of physiological events may be achieved by measuring traits at a transcription level, parallel to measures in the plasma such as metabolites and hormones.

The aim was to investigate the effect of combined butafosfan and cyanocobalamin on liver metabolism of early lactating cows. In addition, the effect of butafosfan and cyanocobalamin on mRNA expression of immune factors in milk cells was measured to investigate mammary gland immune defenses, as it was shown that combined butafosfan and cyanocobalamin decreased the incidence of mastitis (Flasshoff, 1974). Furthermore, the effect of butafosfan and cyanocobalamin on the milk fatty acid composition was evaluated, because vitamin $\mathrm{B}_{12}$ deficiency was observed to alter fatty acid metabolism in liver and brain of the rat (Frenkel et al., 1973), and may affect milk fat synthesis through methylmalonyl CoA (Frobish and Davis, 1977).

\section{MATERIALS AND METHODS}

\section{Animals and Management}

The experimental procedures followed the Swiss Law on Animal Protection and were approved by the Committee of Animal Experiments of the Canton Fribourg, Switzerland. Sixteen multiparous lactating dairy cows $[25 \pm 3$ DIM, $662 \pm 16 \mathrm{~kg}$ of BW; 2 to 8 parities; Holstein (HO) and Swiss Fleckvieh (SF, Holstein $x$ Simmental) breeds] were equally assigned to either an experimental treatment (TG) or control treatment
(CG), based on their parity, breed, and BHBA concentration in the milk (detected with Ketolac strips; Provet AG, Lyssach, Switzerland), for $3 \mathrm{~d}$ and followed for 9 wk thereafter. Cows were held at the Swiss Federal Research Station Agroscope Liebefeld-Posieux (ALP), Posieux, Switzerland. Housing and feeding management of the animals were similar to that described in van Dorland et al. (2009).

\section{Treatment}

The TG cows received $10 \mathrm{~mL} / 100 \mathrm{~kg}$ of $\mathrm{BW}$ combined $10 \%$ butafosfan and $0.005 \%$ cyanocobalamin solution (Catosal; Bayer Animal Health $\mathrm{GmbH}$ ) administered via i.v. catheter into the jugular vein. This injection was performed on $3 \mathrm{~d}$ consecutively at $0715 \mathrm{~h}$ after milking and the morning feeding. The CG cows were treated with a physiological saline solution $(0.9 \% \mathrm{NaCl})$ in the same dose volume per BW as the TG cows.

\section{BW, BCS, and Backfat Thickness}

The cows were automatically weighed daily after the morning milking. The BCS (Edmonson et al., 1989) and the backfat thickness, determined ultrasonically (Bruckmaier et al., 1998), were evaluated on the day before the treatment, and repeated every 2 wk throughout the experimental period.

\section{Blood Collection and Analysis}

Blood samples were taken on the day before the injections, on the third day after the injections, and then weekly until 9 wk of the experimental period. Blood samples were obtained from the jugular vein by using evacuated tubes containing tripotassium EDTA after the morning milking and before feeding at $0630 \mathrm{~h}$. Following centrifugation $\left(3,000 \times \mathrm{g}, 20 \mathrm{~min}, 4^{\circ} \mathrm{C}\right)$ plasma was frozen and stored at $-20^{\circ} \mathrm{C}$ to await analysis. Concentrations of glucose, phosphorus, total cholesterol, albumin, protein, and urea, and activities of aspartate aminotransferase were measured enzymatically with kits from BioMérieux (Marcy-l'Étoile, France; no. 61269, 61571, 61218, 61051, 61602, 61974, and 63212, respectively). Concentrations of NEFA and BHBA were measured enzymatically with kit no. FA115 and RB1007 from Randox Laboratories Ltd. (Ibach, Switzerland). Finally, lactate dehydrogenase was measured enzymatically by using the kit no. AXON00025 from Axon Lab AG (Baden- Dättwil, Switzerland).

\section{Liver Tissue Collection, mRNA Extraction, and Quantitative Real-Time Reverse-Transcriptase PCR}

Liver biopsies were taken following blood sampling at around $0700 \mathrm{~h}$ on the day before, and 3 and $10 \mathrm{~d}$ 
after the treatment. Liver samples were obtained by blind percutaneous needle biopsy (Tru-Cut; Provet AG) under local anesthesia (van Dorland et al., 2009). The samples were placed directly into a RNA stabilization reagent (RNAlater, Ambion Inc.; Applied Biosystems Inc., Austin, TX), and stored at $-80^{\circ} \mathrm{C}$ until analyzed. Total RNA was extracted from liver samples using peqGOLD TriFast (PEQLAB Biotechnologie $\mathrm{GmbH}$, Erlangen, Germany), following quantification determined by absorbance at $260 \mathrm{~nm}$ using a NanoDrop ND-2000 spectrophotometer (NanoDrop Technologies Inc., Wilmington, DE).

Subsequently, $1 \mu \mathrm{g}$ of extracted total RNA was reverse transcribed with 200 U of Moloney Murine Leukemia Virus Reverse Transcriptase RNase H Minus, Point Mutant (Promega Corp., Madison, WI) using 100 pmol random hexamer primers (Invitrogen Corp., Leek, the Netherlands). A master mix containing the following components was prepared: $0.8 \mu \mathrm{L}$ of PCR water, $1.0 \mu \mathrm{L}$ of forward primer $(5 \mathrm{pmol}), 1.0 \mu \mathrm{L}$ of reverse primer $(5$ pmol), and $5.2 \mu \mathrm{L} 2 \mathrm{x}$ SensiMix Plus SYBR-Green (1 $\mathrm{m} M \mathrm{MgCl}_{2}$ ). The mRNA abundance of 31 candidate genes related to metabolism in the liver was measured (Table 1). The PCR quantification was performed with the Rotor-Gene 6000 (Corbett Research Pty Ltd., Sydney, Australia), using the software version 1.7.40. Fluorescence take off was calculated with the threshold program option. Eight microliters of master mix and $2-\mu \mathrm{L}$ sample volume, containing $20 \mathrm{ng}$ of cDNA, were used. The following 3-step PCR program was used: denaturation for $10 \mathrm{~min}$ at $95^{\circ} \mathrm{C}, 40$ cycles of amplification (each consisting of $15 \mathrm{~s}$ at $95^{\circ} \mathrm{C}$, the primerspecific annealing temperature for $30 \mathrm{~s}$ (see Table 1), and extension at $72^{\circ} \mathrm{C}$ for $20 \mathrm{~s}$ and quantification of fluorescence), and finally, a melting curve program (60 to $95^{\circ} \mathrm{C}$ ). The mRNA levels were calculated relative to the expression levels of the housekeeping gene GAPDH, which was stable across time points.

\section{Milk Yield, Sampling, and Analysis}

The milk yield was automatically recorded for each cow individually in the milking parlor during each morning and afternoon milking throughout the experimental period. Milk samples were taken from each cow and each milking on the day before the treatment, on $\mathrm{d}$ 6 after the start of the treatment, and then once weekly until 9 wk of the experimental period. Milk samples were analyzed for their content of fat, protein, lactose, urea, and CN by infrared technique (CombiFoss 6000; Gerber Instrument AG, Illnau-Effretikon, Switzerland) at the laboratory of the Holstein Association of Switzerland (Grangeneuve, Switzerland).
For the collection of milk cells, $2 \mathrm{~L}$ of total milk were collected during the afternoon milking on the day before the experiment and on d 6 after the start of the treatment, followed by centrifugation at $1,500 \times g$ for $30 \mathrm{~min}$ at $4^{\circ} \mathrm{C}$. Following removal of the supernatant, the remainder was dissolved in $200 \mathrm{~mL}$ of cold PBS and centrifuged at $460 \times g$ for $15 \mathrm{~min}$ at $4^{\circ} \mathrm{C}$. Once more, the supernatant was removed and the remaining pellet was dissolved in $500 \mu \mathrm{L}$ of peqGOLD TriFast, and stored at $-80^{\circ} \mathrm{C}$. Total mRNA was extracted, reverse transcribed, and gene quantification was performed by real-time quantitative reverse transcriptase (qRT)-PCR, as described for liver tissue. The mRNA abundance of the 3 candidate genes in the milk cells was measured similarly as for the candidate genes in the liver (Table 2).

Furthermore, 1 composite milk sample per cow was prepared from the morning and afternoon milking on the day before and on d 6 and 13 after the start of the treatment for the analysis of the milk fatty acid (FA) profile. The FA composition of milk samples was determined according to Bligh and Dyer (1959) with modifications from Hallermayer (1976), using FA methyl esters (FAME) prepared by transesterification with trimethylsulfonium hydroxide at room temperature $\left(20-25^{\circ} \mathrm{C}\right)$. The FAME were analyzed using GC (GC 6890; Agilent Technologies Deutschland GmbH, Waldbronn, Germany) to determine the FA distribution profile followed by quantification. The following groups of FA were evaluated: saturated FA, monounsaturated FA (MUFA), and polyunsaturated FA (PUFA). In addition, as part of MUFA, 18:1 trans FA were evaluated, and as part of PUFA, linoleic acid, $\alpha$-linolenic acid, n-3 FA, n-6 FA, and cis9,trans11 conjugated linoleic acid were evaluated.

\section{Statistical Analysis}

Preliminary analysis of data on plasma, milk yield, milk contents, BW, BCS, and ultrasound measurements up to 9 wk after the start of the treatment showed that combined butafosfan and cyanocobalamin did not affect these variables in a long-term manner. Therefore, statistical analyses focused primarily on the day before (covariable) and on the first 2 sampling time points (d 6 and 13) after the start of the treatment, which coincided with the biopsy time points of the liver. In the case of BCS and backfat thickness, only data on d 14 relative to the start of the treatment were evaluated.

All data, including gene expression data, were analyzed using the MIXED procedure of SAS (SAS Institute, 2002-2008) for repeated measures; sampling time point was used as a repeated measure with variance 
Table 1. PCR primers, annealing temperatures, and the PCR product lengths for the genes analyzed in liver tissue

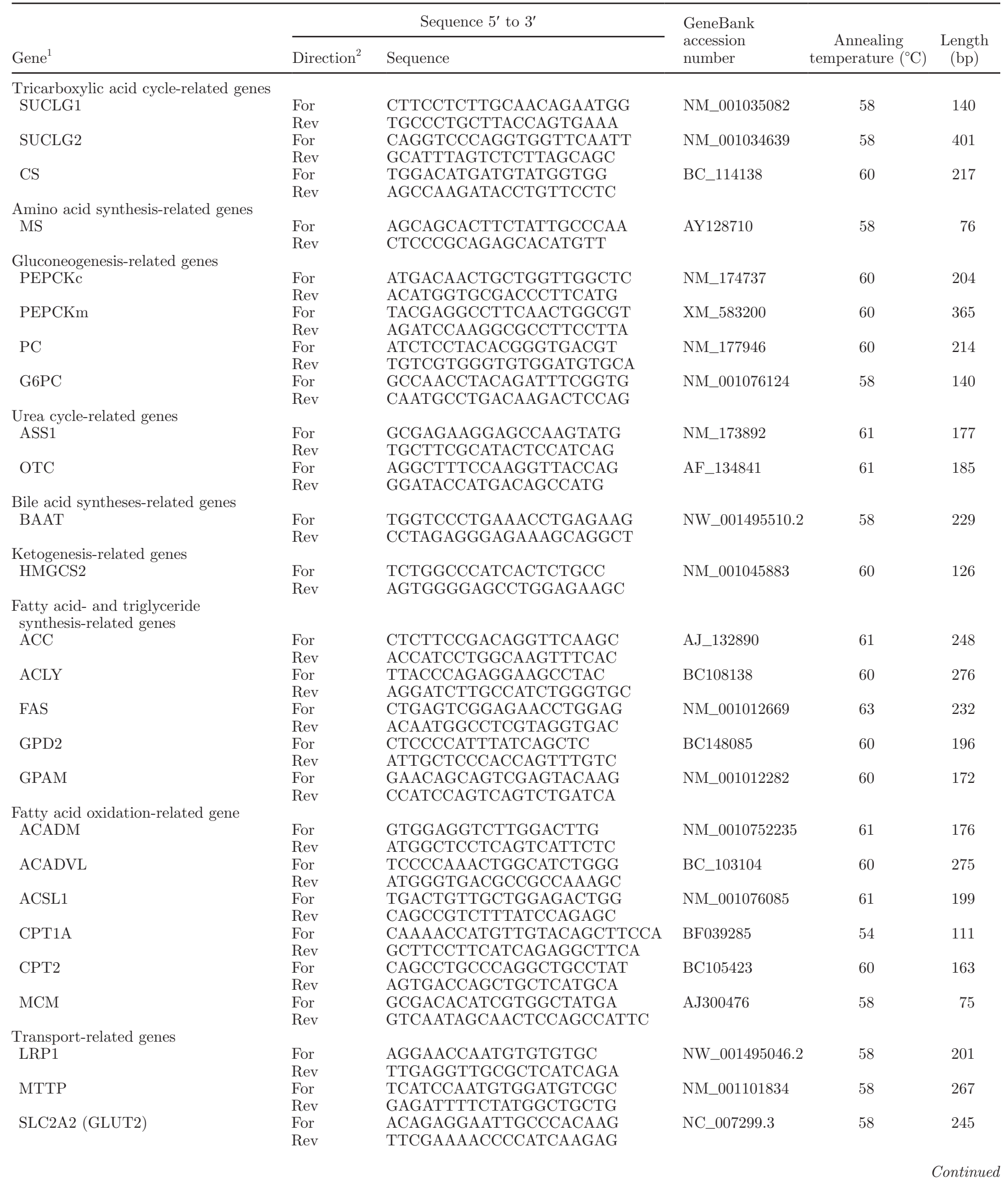


Table 1 (Continued). PCR primers, annealing temperatures, and the PCR product lengths for the genes analyzed in liver tissue

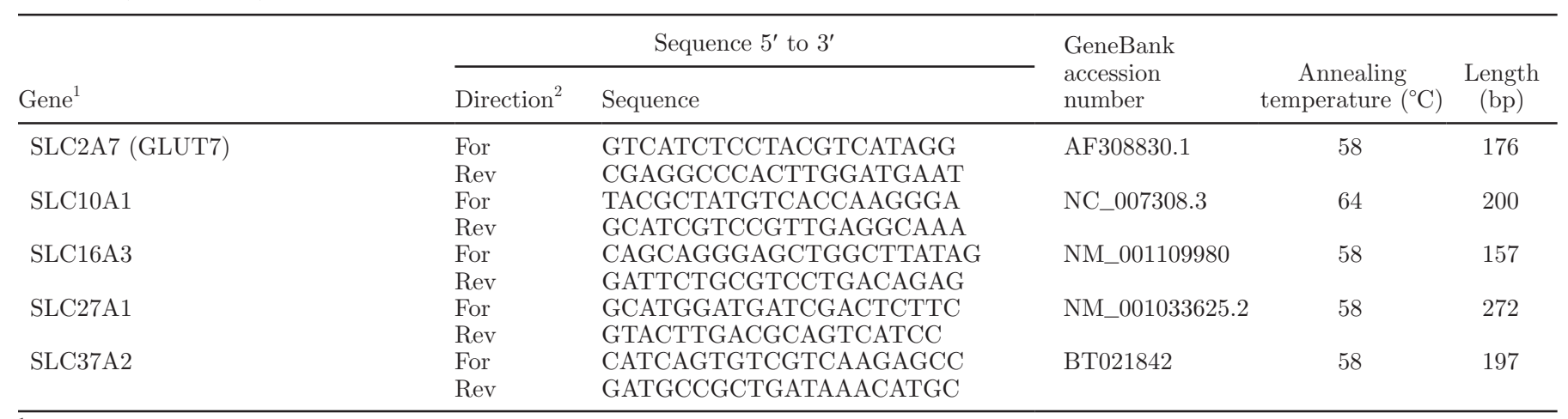

${ }^{1}$ SUCLG1 = succinyl-coenzyme A (CoA) synthetase, subunit 1; SUCLG2, succinyl-CoA synthetase, subunit 2; CS = citrate synthase; MS = methionine synthase; PEPCKc $=$ cytosolic phosphoenolpyruvate carboxykinase; PEPCKm = mitochondrial phosphoenolpyruvate carboxykinase; $\mathrm{PC}=$ pyruvate carboxylase; G6PC = glucose-6-phosphatase, catalytic unit; ASS1 = argininosuccinate synthetase 1; OTC = ornithine transcarbamylase; BAAT = bile acid CoA: amino acid N-acyltransferase; HMGCS2 = 3-hydroxy-3-methylglutaryl-CoA synthase 2; ACC = acetyl-CoA carboxylase; ACLY = ATP citrate lyase; FAS = fatty acid synthase; GPD2 = glycerol-3-phosphate dehydrogenase 2; GPAM = mitochondrial glycerol-3-phosphate acyltransferase; ACADM = acyl-CoA dehydrogenase medium chain; ACADVL = acyl-CoA dehydrogenase very long chain; ACSL1 = acyl-CoA synthetase long-chain family member 1 ; CPT1A = carnitine palmitoyltransferase $1 \mathrm{~A}$; CPT2 = carnitine palmitoyltransferase $2 ; \mathrm{MCM}=$ methylmalonyl-CoA-mutase; LRP1 = low-density lipoprotein receptor-related protein; MTTP $=$ microsomal triglyceride transfer protein; SLC2A2 = solute carrier family 2, member 2; SLC2A7 = solute carrier family 2, member 7; SLC10A1 = solute carrier family 10, member 1; SLC16A3 = solute carrier family 16, member 3; SLC27A1 = solute carrier family 27, member 1; SLC37A2 = solute carrier family 37 , member 2 .

${ }^{2}$ For $=$ forward primer; Rev $=$ reverse primer.

components as covariance structure. The statistical model included the effect of treatment (TG or CG), sampling time point (d 14 after the start of the treatment for data on BW, BCS, and ultrasound measurements; $d 6$ after the start of the treatment for mRNA abundance data from milk cells; and d 6 or 13 after the start of the treatment for all other data), breed type (HO or SF), and parity $(<4$ or $\geq 4)$. The interaction treatment by sampling time point was not included in the final model, as it was nonsignificant. Data obtained on $d-1$ relative to the start of the treatment was included as covariable in the model to compensate for initial differences between the TG and CG cows. Furthermore, cow was used as repeated subject. Differences were considered significant if $P<0.05$, and were considered tendencies if $P<0.10$. Data are presented as means \pm standard error of the means.

\section{RESULTS}

Over 64 traits were studied to evaluate the effect of combined butafosfan and cyanocobalamin in early lactating dairy cows primarily on hepatic metabolism, and additionally on mammary immune defense and milk fat quality.

In plasma (Table 3), the concentration of inorganic phosphorus was lower $(P=0.046)$ in the TG cows $(1.25 \pm 0.08 \mathrm{mmol} / \mathrm{L}$, means $\pm \mathrm{SEM}$, across $\mathrm{d} 6$ and 13) after the treatment than in the CG cows $(1.33 \pm$ $0.07 \mathrm{mmol} / \mathrm{L}$, across d 6 and 13). Furthermore, in TG compared with CG cows, plasma NEFA concentrations tended to be lower $(P=0.10)$ after treatment $(0.37 \pm$ 0.07 vs. $0.63 \pm 0.15 \mathrm{mmol} / \mathrm{L}$, respectively, across $\mathrm{d} 6$ and 13; Table 3). The plasma BHBA concentrations were not affected by treatment and were $0.65 \pm 0.13$, $0.52 \pm 0.07$, and $0.51 \pm 0.06 \mathrm{mmol} / \mathrm{L}$ for all cows on

Table 2. PCR primers, annealing temperatures, and the PCR product lengths for the genes analyzed in the milk cells

\begin{tabular}{llllc}
\hline \multirow{2}{*}{$\begin{array}{l}\text { Immune } \\
\text { defense-related gene }\end{array}$} & \multicolumn{1}{c}{ Sequence $5^{\prime}$ to $3^{\prime}$} & $\begin{array}{l}\text { GeneBank } \\
\text { accession } \\
\text { number }\end{array}$ & $\begin{array}{c}\text { Annealing } \\
\text { temperature }\left({ }^{\circ} \mathrm{C}\right)\end{array}$ & $\begin{array}{c}\text { Length } \\
(\mathrm{bp})\end{array}$ \\
\cline { 2 - 5 } TNF- ${ }^{1}$ & Direction $^{2}$ & Sequence & NM_173966 & 60 \\
IL-8 & For & CCACGTTGTAGCCGACATC & 155 \\
IL-1b & Rev & CCCTGAAGAGGACCTGTGAG & 60 \\
& For & ATGACTTCCAAGCTGGCTGTTG & EU276073 & 150 \\
\hline
\end{tabular}

${ }^{1} \mathrm{TNF}-\alpha=$ tumor necrosis factor $\alpha$.

${ }^{2}$ For $=$ forward primer; Rev $=$ reverse primer. 
Table 3. Mean \pm standard error of the means of blood plasma concentration of metabolites and enzymes after the treatment with Catosal ${ }^{1}$ or saline (control) in early lactating dairy cows

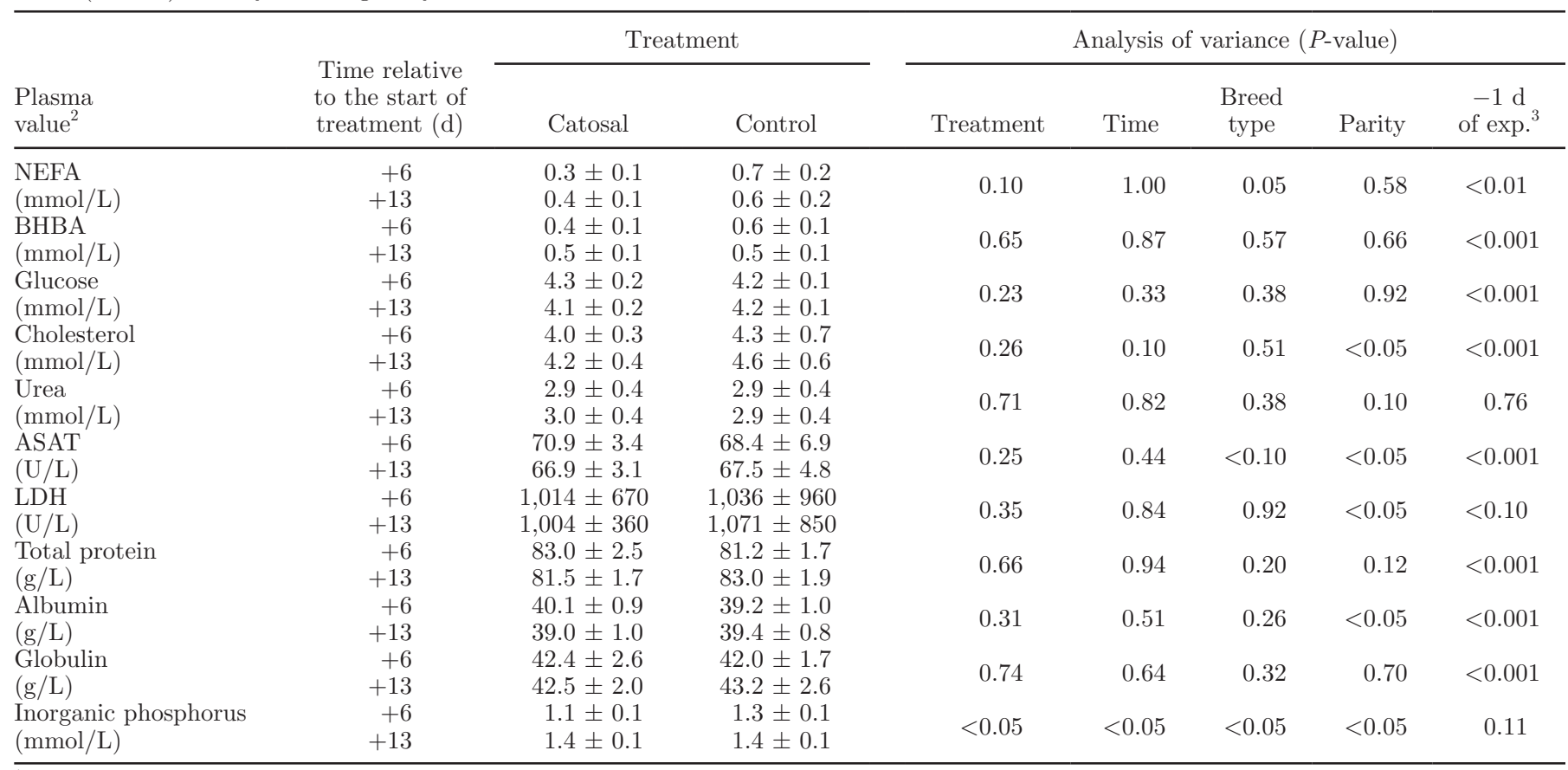

${ }^{1}$ Bayer Animal Health GmbH (Leverkusen, Germany).

${ }^{2} \mathrm{ASAT}=$ aspartate aminotransferase $; \mathrm{LDH}=$ lactate dehydrogenase.

${ }^{3}$ Day 1 before the treatment $(-1 \mathrm{~d})$ was taken as a covariable in the model during statistical analysis.

$\mathrm{d}-1,6$, and 13 , respectively. Furthermore, no treatment effects were observed for the other studied plasma variables (Table 3 ).

In the liver, mRNA abundance of acyl-CoA synthetase long-chain family member 1 (ACSL1), an enzyme involved in fatty acid $\beta$-oxidation, was significantly affected by combined butafosfan and cyanocobalamin. In TG cows, the mRNA abundance was lower $(P=0.025$; Figure 1) across time points after the treatment than in the CG cows. Furthermore, a tendency for a treatment difference was observed for the mRNA abundance encoding for 3-hydroxy-3-methylglutaryl-CoA synthase (HMGCS2), an enzyme involved in ketogenesis $(P=$ 0.096; Table 4). Application of combined butafosfan and cyanocobalamin resulted in a higher mRNA abundance in CG cows compared with TG cows $[20.9 \pm 0.2$ cycle threshold $(\mathbf{C T}) \log _{2}$ vs. $20.6 \pm 0.2 \mathrm{CT} \log _{2}$, respectively, across $\mathrm{d} 6$ and 13]. The mRNA abundance of citrate synthase, an enzyme of the TCA cycle, tended to be lower $(P=0.07)$ in TG cows compared with CG cows after treatment $\left(13.5 \pm 0.2\right.$ vs. $14.2 \pm 0.3 \mathrm{CT} \log _{2}$, respectively, across d 6 and 13; Table 4).

With regard to the measured mRNA expression of immune related traits in the milk cells, no significant effect of treatment was observed (Table 5). A treatment effect for daily milk production after the treatment across d 6 and 13 of the study was observed $(P$

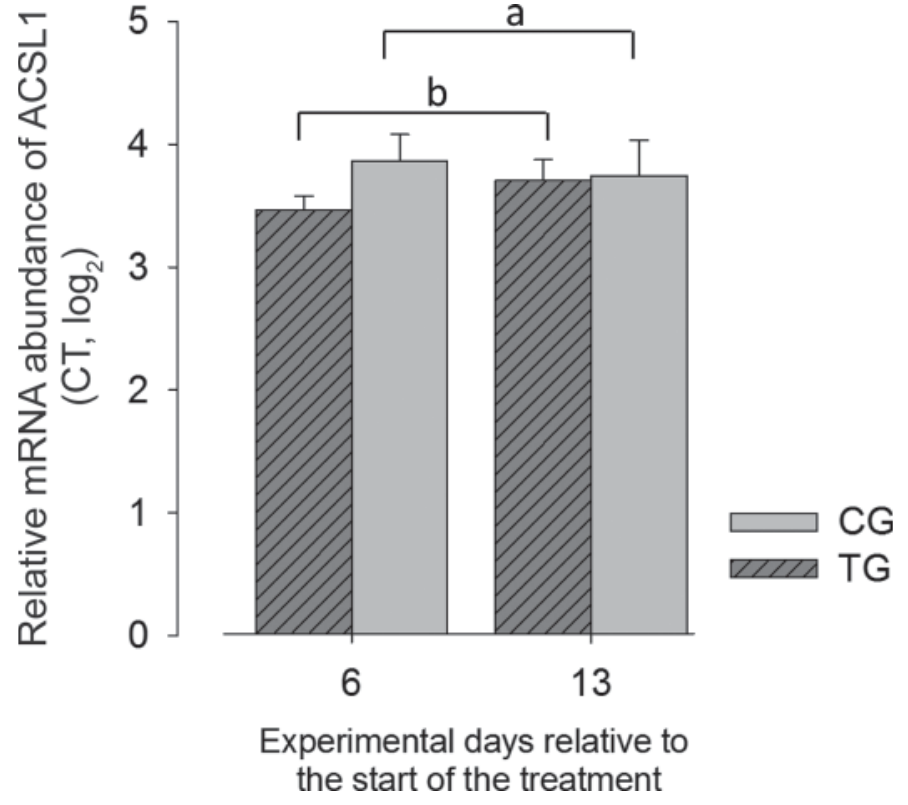

Figure 1. Mean \pm standard error of the means of mRNA abundance [cycle threshold (CT), $\log _{2}$ ] of acyl-coenzyme A (CoA) synthetase long-chain 1 (ACSL1) after the combined butafosfan and cyanocobalamin (TG) or control treatment (CG) in dairy cows. Different letters $(\mathrm{a}, \mathrm{b})$ indicate differences between treatments across time points after the treatment $(P=0.025)$. 
Table 4. Mean \pm standard error of the means of mRNA abundance [cycle threshold $(\mathrm{CT}), \log _{2}$ ] of variables in the liver tissue after the treatment with Catosal ${ }^{1}$ or saline (control) in early lactating dairy cows

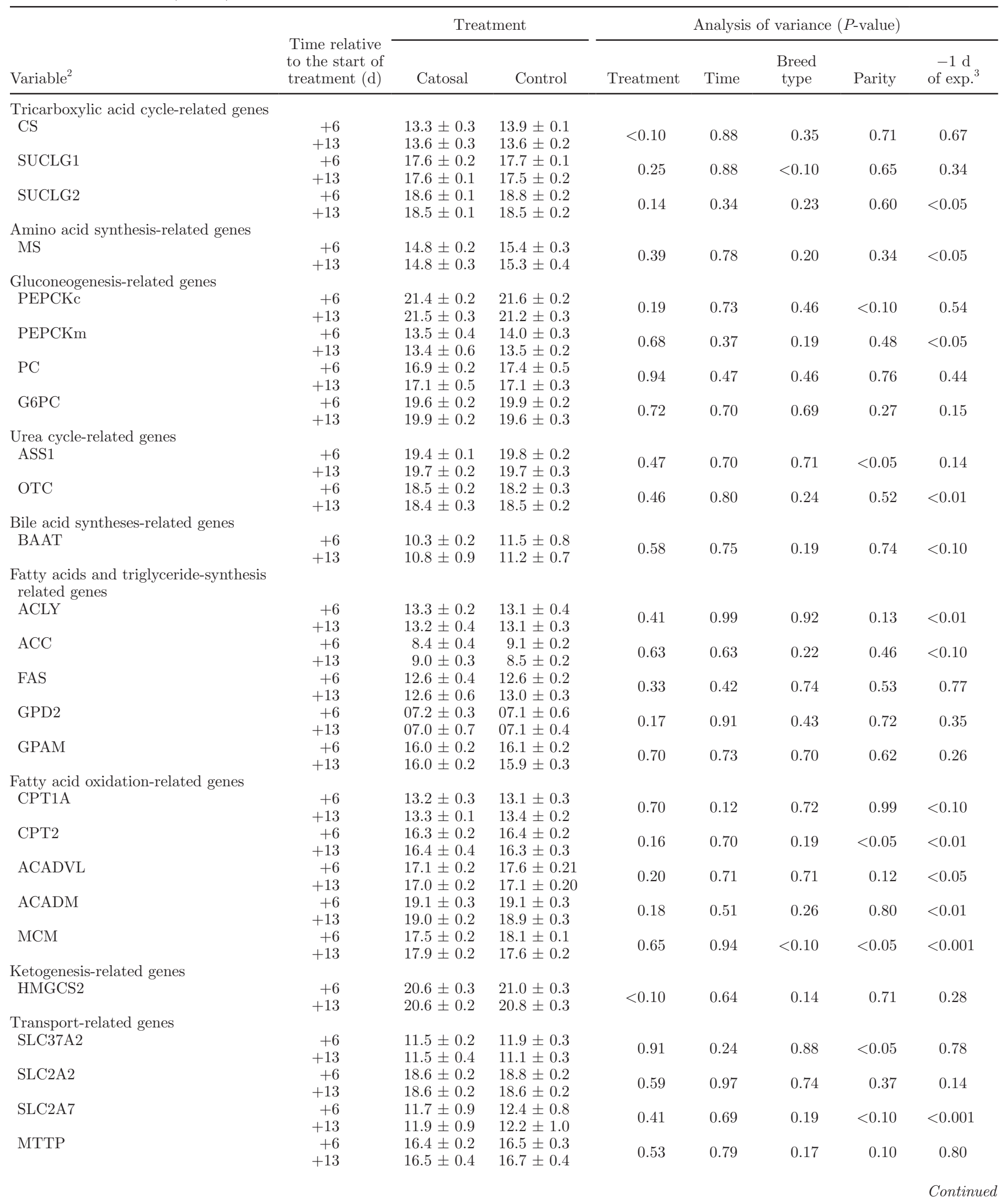


Table 4 (Continued). Mean \pm standard error of the means of mRNA abundance [cycle threshold $(\mathrm{CT}), \log _{2}$ ] of variables in the liver tissue after the treatment with Catosal ${ }^{1}$ or saline (control) in early lactating dairy cows

\begin{tabular}{|c|c|c|c|c|c|c|c|c|}
\hline Variable $^{2}$ & $\begin{array}{l}\text { Time relative } \\
\text { to the start of } \\
\text { treatment }(\mathrm{d})\end{array}$ & \multicolumn{2}{|c|}{ Treatment } & \multicolumn{5}{|c|}{ Analysis of variance ( $P$-value) } \\
\hline SLC27A1 & $\begin{array}{r}+6 \\
+13\end{array}$ & $\begin{array}{l}10.9 \pm 0.4 \\
11.0 \pm 0.3\end{array}$ & $\begin{array}{l}11.2 \pm 0.2 \\
10.2 \pm 0.7\end{array}$ & 0.56 & 0.98 & 0.65 & 0.68 & 0.62 \\
\hline LRP1 & $\begin{array}{r}+6 \\
+13\end{array}$ & $\begin{array}{l}18.3 \pm 0.2 \\
18.3 \pm 0.1\end{array}$ & $\begin{array}{l}18.5 \pm 0.2 \\
18.0 \pm 0.2\end{array}$ & 0.41 & $<0.10$ & 0.94 & 0.49 & 0.14 \\
\hline
\end{tabular}

${ }^{1}$ Bayer Animal Health GmbH (Leverkusen, Germany).

${ }^{2} \mathrm{CS}=$ citrate synthase; SUCLG1 = succinyl-coenzyme A (CoA) synthetase, subunit 1 ; SUCLG2 = succinyl-CoA synthetase, subunit 2; MS = methionine synthase; PEPCKc $=$ cytosolic phosphoenolpyruvate carboxykinase; PEPCKm $=$ mitochondrial phosphoenolpyruvate carboxykinase; $\mathrm{PC}=$ pyruvate carboxylase; $\mathrm{G} 6 \mathrm{PC}=$ glucose-6-phosphatase, catalytic unit; ASS1 = argininosuccinate synthetase 1; OTC = ornithine transcarbamylase; BAAT = bile acid CoA: amino acid N-acyltransferase; ACLY = ATP citrate lyase; ACC = acetyl-CoA carboxylase; FAS = fatty acid synthase; GPD2 = glycerol-3-phosphate dehydrogenase 2; GPAM = mitochondrial glycerol-3-phosphate acyltransferase; CPT1A = carnitine palmitoyltransferase $1 \mathrm{~A} ; \mathrm{CPT} 2=$ carnitine palmitoyltransferase 2 ; ACADVL = acyl-CoA dehydrogenase very long chain; ACADM $=$ acyl-CoA dehydrogenase medium chain; $\mathrm{MCM}=$ methylmalonyl-CoA mutase; HMGCS2 = 3-hydroxy-3-methylglutaryl-CoA synthase 2; SLC37A2 = solute carrier family, member $2 ;$ SLC2A2 = solute carrier family 2, member 2; SLC2A7 = solute carrier family 2, member 7; MTTP $=$ microsomal triglyceride transfer protein; SLC16A3 = solute carrier family 16, member 3; SLC27A1 = solute carrier family 27 , member 1 ; SLC10A1 = solute carrier family 10, member 1; LRP1 = low-density lipoprotein receptor-related protein.

${ }^{3}$ Day 1 before the treatment $(-1 \mathrm{~d})$ was taken as a covariable in the model during statistical analysis.

$<0.001$, Table 6) with TG cows producing more milk per day $(41.1 \pm 0.9 \mathrm{~kg})$ than $\mathrm{CG}$ cows $(38.5 \pm 0.7 \mathrm{~kg})$. The milk composition was not affected by combined butafosfan and cyanocobalamin (Table 6). The milk fat $\alpha$-linolenic acid content tended to be lower in TG $(0.77$ $\pm 0.03 \mathrm{~g} / 100 \mathrm{~g}$ of total milk fat, across d 6 and 13) compared with CG cows $(0.83 \pm 0.02 \mathrm{~g} / 100 \mathrm{~g}$ of total milk fat; $P=0.08$; Table 7). Furthermore, no effect of combined butafosfan and cyanocobalamin application on BW, BCS, and the backfat and muscle thickness were observed (Table 8).

\section{DISCUSSION}

One of the primary fields of combined butafosfan and cyanocobalamin application is the treatment of ketosis in dairy cows. But, other uses and beneficial effects of combined butafosfan and cyanocobalamin include prevention of milk fever (Schuh, 1994), improvement of fertility, reproductive and productive performance (Flasshoff, 1974; Cuteri et al., 2008; Deniz et al., 2010), decrease of stress (Simon, 1990), and faster recovery after surgery for abomasal displacement (Fürll et al., 2006). In the present study, the slightly higher milk yield in the treated cows after the treatment was not surprising and confirmed observations from Cuteri et al. (2008), who observed increased milk production after application of combined butafosfan and cyanocobalamin. On the other hand, the unaffected milk contents in the present study do not support Fürll et al. (2010), who reported higher milk lactose content in cows treated with combined butafosfan and cyanocobalamin compared with control cows. This may be explained by the timing of the treatment, because Fürll et al. (2010) treated cows 2 to 3 wk before parturition. In addition, Graulet et al. (2007) observed effects

Table 5. Mean \pm standard error of the means of mRNA abundance [cycle threshold $(\mathrm{CT}), \log _{2}$ ] of immune defense traits in the milk cells after the treatment with Catosal ${ }^{1}$ or saline (control) in early lactating dairy cows

\begin{tabular}{|c|c|c|c|c|c|c|c|}
\hline \multirow[b]{2}{*}{ Variable $^{2}$} & \multirow{2}{*}{$\begin{array}{l}\text { Time relative } \\
\text { to the start of } \\
\text { treatment }(\mathrm{d})\end{array}$} & \multicolumn{2}{|c|}{ Treatment } & \multicolumn{4}{|c|}{ Analysis of variance ( $P$-value) } \\
\hline & & Catosal & Control & Treatment & $\begin{array}{c}\text { Breed } \\
\text { type }\end{array}$ & Parity & $\begin{array}{c}-1 \mathrm{~d} \\
\text { of exp. }\end{array}$ \\
\hline IL8 & +6 & $19.5 \pm 1.0$ & $20.3 \pm 0.3$ & 0.66 & 0.89 & 0.38 & 0.11 \\
\hline IL1b & +6 & $18.1 \pm 0.8$ & $19.1 \pm 0.5$ & 0.61 & 0.83 & 0.31 & 0.82 \\
\hline
\end{tabular}

${ }^{1}$ Bayer Animal Health GmbH (Leverkusen, Germany).

${ }^{2} \mathrm{TNF} \alpha=$ tumor necrosis factor $\alpha$.

${ }^{3}$ Day 1 before the treatment $(-1 \mathrm{~d})$ was taken as a covariable in the model during statistical analysis. 
Table 6. Mean \pm standard error of the means of milk yield and composition after the treatment with Catosal ${ }^{1}$ or saline (control) in early lactating dairy cows

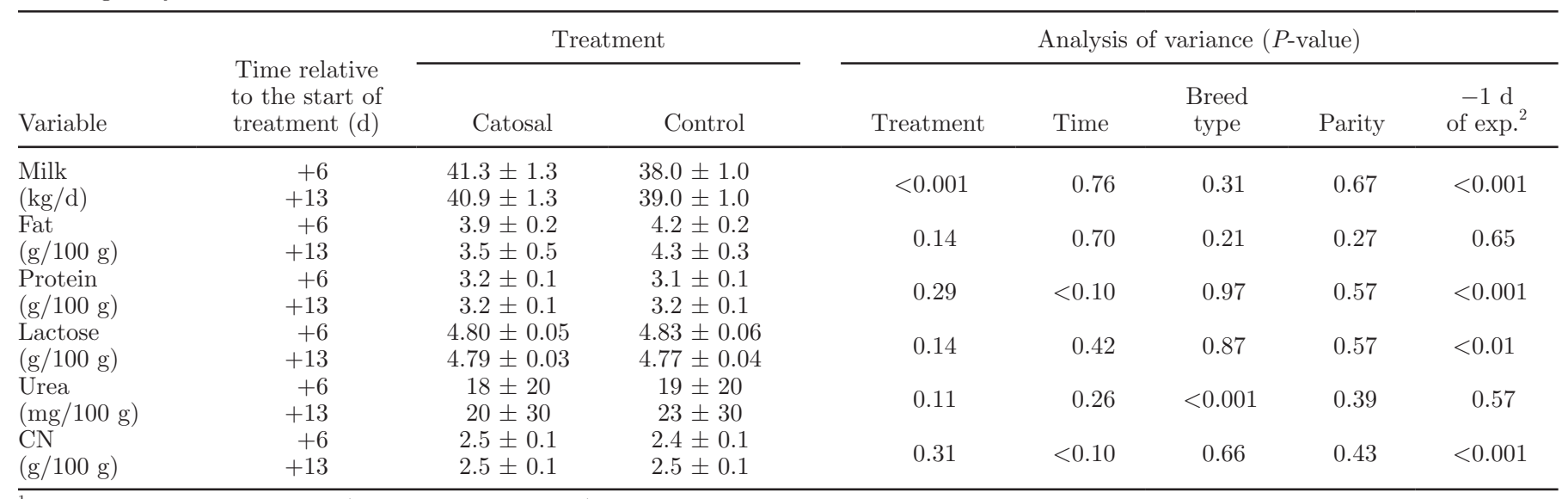

${ }^{1}$ Bayer Animal Health GmbH (Leverkusen, Germany).

${ }^{2}$ Day 1 before the treatment $(-1 \mathrm{~d})$ was taken as a covariable in the model during statistical analysis.

of dietary vitamin $\mathrm{B}_{12}$ and folic acid on milk contents with lower milk urea and higher milk fat content in the treated compared with control cows.

Fürll et al. (2010) reported higher plasma inorganic phosphorus concentration in the treated compared with the control cows, although butafosfan injection in the cows did not immediately result in an increase in the serum phosphorus concentration, in contrast to the current study. The phosphorus in butafosfan may not directly increase plasma phosphorus concentrations in the animal. Delport et al. (2006) and Rollin et al.
(2010) confirm the results of Fürll et al. (2010), as they did not observe an effect on the plasma phosphorus concentration due to butafosfan treatment. Fürll et al. (2010) explained their observations by the numerically higher milk production of the control compared with the treatment cows, because lactation is a major drain on phosphorus. This may explain the lower plasma phosphorus concentration with the concomitant higher milk yield in the TG compared with the CG cows in the present study, which may, in large part, be related to the initially higher milk yield in TG cows compared

Table 7. Mean \pm standard error of the means of milk fatty acids pattern after the treatment with Catosal ${ }^{1}$ or saline (control) in early lactating dairy cows

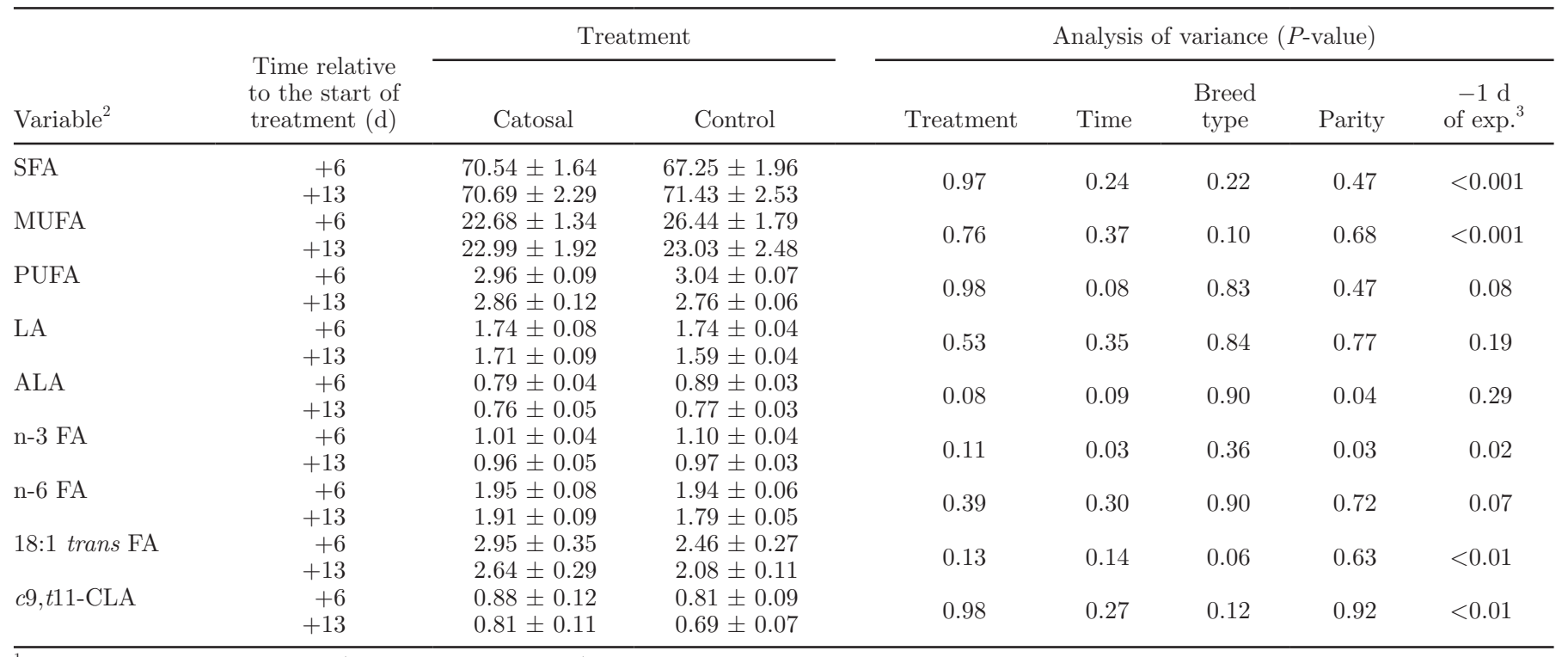

${ }^{1}$ Bayer Animal Health GmbH (Leverkusen, Germany).

${ }^{2} \mathrm{SFA}=$ saturated fatty acids; MUFA = monounsaturated fatty acids; PUFA = polyunsaturated fatty acids; LA = linoleic acids; ALA = $\alpha$-linolenic acids; $\mathrm{n}-3 \mathrm{FA}=\mathrm{n}-3$ fatty acids; $\mathrm{n}-6 \mathrm{FA}=\mathrm{n}-6$ fatty acids; $18: 1$ trans $\mathrm{FA}=18: 1$ trans fatty acids; $c 9, t 11$-CLA $=$ cis-9, trans-11 conjugated linoleic acids.

${ }^{3}$ Day 1 before the treatment $(-1 \mathrm{~d})$ was taken as a covariable in the model during statistical analysis. 
Table 8. Mean \pm standard error of the means of BW, BCS, and back fat and muscle thickness after the treatment with Catosal ${ }^{1}$ or saline (control) in early lactating dairy cows

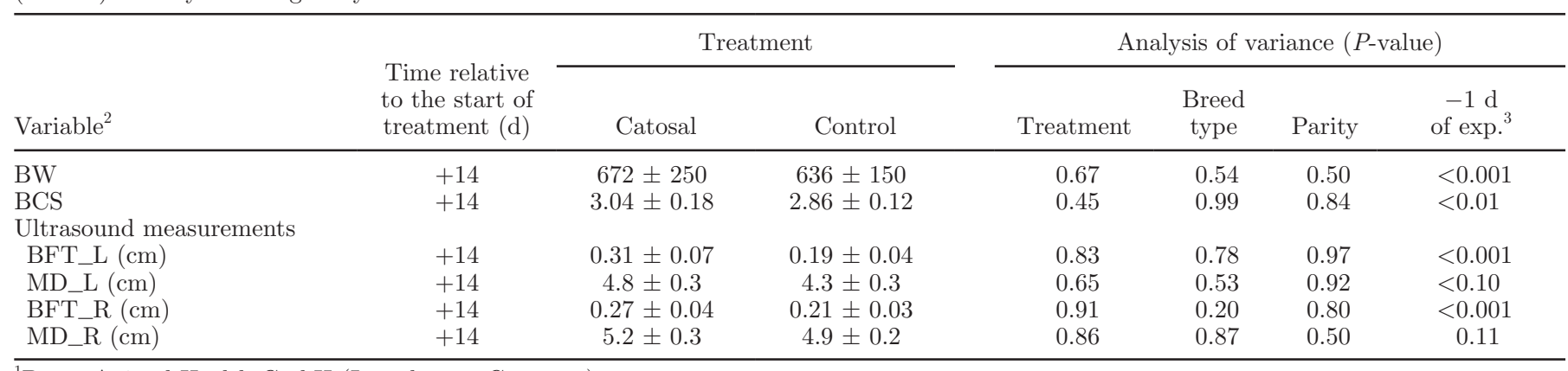

${ }^{1}$ Bayer Animal Health GmbH (Leverkusen, Germany).

${ }^{2} \mathrm{BFT} \_\mathrm{L}=$ back fat thickness loin; MD_L = muscle diameter, loin; BFT_R = back fat thickness, rib; MD_R = muscle diameter, rib.

${ }^{3}$ Day 1 before the treatment $(-1 \mathrm{~d})$ was taken as a covariable in the model during statistical analysis.

with CG cows, and to a lesser extent, related to the treatment with combined butafosfan and cyanocobala$\min$.

At present, gene expression data are increasingly used to investigate mechanisms underlying physiological functions and processes, and the method allows a large number of genes to be studied from only a small tissue sample, repetitively taken from the cow over time (Bruckmaier and van Dorland, 2010). Combined butafosfan and cyanocobalamin treatment in the present study affected mRNA expression of a gene encoding enzymes involved in 1 metabolic pathway: fatty acid oxidation (ACSL1). In Graber et al. (2010), mRNA abundance of ACSL1 was upregulated in wk 4 postpartum, which reflected the increase in oxidation of fatty acids due to an elevated level of NEFA during a negative energy balance postpartum. Possible differences in feed intake between the cows of the 2 treatments may have resulted in the observed differences in the liver, although in the present study, feed intake was not monitored and it was assumed that under standardized feeding conditions, feed intake would be similar under both treatments.

Even though the dosage of combined butafosfan and cyanocobalamin applied in the present study was high with $10 \mathrm{~mL} / 100 \mathrm{~kg}$ of $\mathrm{BW}$ on $3 \mathrm{~d}$ consecutively, in comparison with other studies (Fürll et al., 2006; Lohr et al., 2006; Sarasola et al., 2008), only few effects were observed. The dosage used in the other mentioned studies was $5 \mathrm{~mL} / 100 \mathrm{~kg}$ of BW given on 1 to 3 consecutive days. In the present study, butafosfan and cyanocobalamin was administered in dairy cows that did not suffer from disorders, whereas in Fürll et al. (2006), Lohr et al. (2006), and Sarasola et al. (2008), cows with subclinical and secondary ketosis were treated. Therefore, in Fürll et al. (2006), a mean blood BHBA concentration of $1.7 \mathrm{mmol} / \mathrm{L}$ in the cows prior to treatment was observed. In addition, Sarasola et al. (2008) and Lohr et al. (2006) measured a plasma BHBA concentration of $>1.2 \mathrm{mmol} / \mathrm{L}$ and $3.5 \mathrm{mmol} / \mathrm{L}$, respectively, in the cows before treatment. Duffield et al. (1997) indicated that a BHBA concentration $>1.2 \mathrm{mmol} / \mathrm{L}$ is a concentration associated with subclinical signs of ketosis, which confirms that the cows in the present study, with $0.65 \pm 0.13 \mathrm{mmol} / \mathrm{L}$ BHBA concentration before the treatment, were, generally, not ketotic.

In studies from Krdzalic and Curcic (1976), Sarasola et al. (2008), and Fürll et al. (2010), significant effects of combined butafosfan and cyanocobalamin application on plasma measures (e.g., phosphorus, glucose, and BHBA) were observed after the treatment, but the extent of the effect was higher several days after the end of the application of combined butafosfan and cyanocobalamin. Therefore, in the present study, it was decided to collect the first samples $3 \mathrm{~d}$ after the end of the application. It remains to be investigated which of the metabolic challenge or the sampling time points related to the end of the treatment was most important for evaluation of combined butafosfan and cyanocobalamin's mode of action in the liver.

In conclusion, combined butafosfan and cyanocobalamin application in dairy cows, without disorders and without high plasma BHBA concentrations, had certain effects on plasma, hepatic, and production variables in early lactating dairy cows. Despite the low metabolic challenge in early lactation of the studied animals, represented by low plasma BHBA and NEFA and high glucose concentrations, some significant effects were obvious. The obtained results included effects on mRNA expression of ACSL1 in the liver, which is involved in fatty acid oxidation. This is the first approach to show the mode of action of combined butafosfan and cyanocobalamin on the mRNA expression of a gene in the liver. More studies are needed to understand the mode of action of combined butafosfan and cyanocobalamin in detail. We conclude that combined butafosfan and 
cyanocobalamin effects may be more obvious in dairy cows that suffer from high metabolic load in early lactation, including high plasma BHBA concentrations.

\section{ACKNOWLEDGMENTS}

The expert technical assistance of C. Morel, C. Philipona, and Y. Zbinden (Veterinary Physiology, University of Bern, Switzerland) is gratefully appreciated. Furthermore, H. Kienberger (Animal Breeding, Technical University of München, Germany) and M. Janovsky (Animal Nutrition, Technical University of München, Germany) are thanked for the analysis of the fatty acid pattern in milk.

\section{REFERENCES}

Bailey, L. B., and J. F. Gregory III. 1999. Folate metabolism and requirements. J. Nutr. 129:779-782.

Berg, J. M., J. L. Tymoczko, and L. Stryer. 2006. Glycolysis and gluconeogenesis. Pages 433-474 in Biochemistry. 6th ed. J. M. Berg, J. L. Tymoczko, and L. Stryer, ed. W. H. Freeman and Co., New York, NY.

Bligh, E. G., and W. J. Dyer. 1959. A rapid method of total lipid extraction and purification. Can. J. Biochem. Physiol. 37:911-917.

Bruckmaier, R. M., E. Lehmann, D. Hugi, H. M. Hammon, and J. W. Blum. 1998. Ultrasonic measurement of longissimus dorsi muscle and backfat, associated with metabolic and endocrine traits, during fattening of intact and castrated male cattle. Livest. Prod. Sci. 53:123-124.

Bruckmaier, R. M., and H. A. van Dorland. 2010. Advantage of complementary liver transcripts to understand metabolic biodiversity in dairy cows? Pages 469-478 in 3rd Int. European Federation for Animal Science (EAAP) Symp. Energy Protein Metab. Nutr., Parma, Italy. EAAP publication No. 127. Wageningen Academic Publishers, Wageningen, the Netherlands.

Cunningham, J. G. 2002. Textbook of Veterinary Physiology. 3rd ed. W. B. Saunders Co., Philadelphia, PA.

Cuteri, V., L. Nisoli, A. R. Attili, A. Romero Tejeda, S. Preziuso, and A. Fruganti. 2008. Clinical field evaluation of a butafosfan + vitamin B12 compound (Phosphorum B12/Catosal) in the treatment of subclinical ketosis in dairy cows. Hungarian Vet. J. 130(Suppl. 1):16-17. (Abstr.).

Delport, P. C., B. Schmidt, and L. Fourie. 2006. Efficacy and safety of Catosal (synonym Coforta) as a supportive treatment of parturient paresis in cows. Poster no. PS4-120 in Proc. of the 24th World Buiatrics Congr., Nice, France.

Deniz, A., S. Watanapongchati, and S. Aiumlamai. 2010. Effects of original combination of butafosfan and vitamin $\mathrm{B}_{12}$ and generics from Asia on reproduction parameters in cattle. Page 391 in Proc. 26th World Buiatrics Congr., Santiago, Chile.

Duffield, T. F., D. F. Kelton, K. E. Leslie, K. D. Lissemore, and J. H. Lumsden. 1997. Use of test day milk fat and milk protein to detect subclinical ketosis in dairy cattle in Ontario. Can. Vet. J. 38:713-718.

Edmonson, A. J., I. J. Lean, L. D. Weaver, T. Farver, and G. Webster. 1989. A body condition scoring chart for Holstein dairy cows. J. Dairy Sci. 72:68-78.

Flasshoff, F. H. 1974. Clinical and chemical blood serum investigations in cattle and treatment studies with ornithine-aspartate-product HMV 20 and with Catosal for the reduction of fertility and health disorders. PhD Thesis. Tierärztliche Hochschule, Hannover, Germany.

Frenkel, E. P., R. L. Kitchens, and J. M. Johnston. 1973. The effect of vitamin $\mathrm{B}_{12}$ deprivation on the enzymes of fatty acid synthesis. J. Biol. Chem. 248:7540-7546.
Frobish, R. A., and C. L. Davis. 1977. Theory involving propionate and vitamin $\mathrm{B}_{12}$ in the low milk fat syndrome. J. Dairy Sci. 60:268-273.

Fürll, M., A. Deniz, B. Westphal, C. Illing, and P. D. Constable. 2010. Effect of multiple intravenous injections of butaphosphan and cyanocobalamin on the metabolism of periparturient dairy cows. J. Dairy Sci. 93:4155-4164.

Fürll, M., T. Witteck, S. Gengenbach, and B. Schmidt. 2006. Effects of pre-operative application of butaphosphan and cyanocobalamin on reconvalescence clinico-chemical parameters, antioxidative metabolism and postoperative abomasal emptying in cows with abomosal dislocation. Tierärztliche Praxis 34:351-356.

Graber, M., S. Kohler, T. Kaufmann, M. G. Doherr, R. M. Bruckmaier, and H. A. van Dorland. 2010. A field study on characteristics and diversity of gene expression in the liver of dairy cows during the transition period. J. Dairy Sci. 93:5200-5215.

Graulet, B., J. J. Matte, A. Desrochers, L. Doepel, M.-F. Palin, and C. L. Girard. 2007. Effects of dietary supplements of folic acid and vitamin $\mathrm{B}_{12}$ on metabolism of dairy cows in early lactation. J. Dairy Sci. 90:3442-3455.

Grünberg, W., R. Staufenbiel, P. D. Constable, H. M. Dann, D. E. Morin, and J. K. Drackley. 2009. Liver phosphorus content in Holstein-Friesian cows during the transition period. J. Dairy Sci. 92:2106-2117.

Hallermayer, R. 1976. A rapid method to determine fat content in food. Dtsch. Lebensmitt. Rundsch. 10:356-359.

Kennedy, D. G., W. J. Blanchflower, J. M. Scott, D. G. Weir, A. M. Molloy, S. Kennedy, and P. B. Young. 1992. Cobalt-vitamin B-12 deficiency decreases methionine synthase activity and phospholipid methylation in sheep. J. Nutr. 122:1384-1390.

Krdzalic, P., and M. Curcic. 1976. Die Möglichkeit einer Indigestions Therapie bei Kühen mit Catosal und Methaphylaxe der subklinischen Ketose. Veterinarski Glasnik 8:687-693.

Larscheid, H.-P. 1994. Untersuchung zur Wirkung von Butafosfan (Bayer/Leverkusen) in der Preventive und Therapie der Neugeborenen-Enteritis und enzootischen Bronchopneumonie der Kälber. DVM Thesis. Justus-Liebig-University, Giessen, Germany.

Lohr, B., B. Brunner, and H. Kanowitz. 2006. Clinical efficacy of Catosal in the treatment of ketosis in cows with left abomasal displacement. Tierarztl. Umsch. 61:187-190.

Rollin, E., R. D. Berghaus, P. Rapnicki, S. M. Godden, and M. W. Overton. 2010. The effect of injectable butaphosphan and cyanocobalamin on postpartum serum $\beta$-hydroxybutyrate, calcium, and phosphorus concentrations in dairy cattle. J. Dairy Sci. 93:978987.

Sarasola, P., U. Aramendi, U. Spiecker-Hauser, and B. Schmidt. 2008. Preliminary results from an ongoing field study on the effect of Catosal in the treatment of subclinical ketosis in cows. Hungarian Vet. J. 130(Suppl. 1):26-27. (Abstr.).

SAS Institute. 2002-2008. SAS/STAT User's Guide. Version 9.2. SAS Institute Inc., Cary, NC.

Schuh, R. 1994. Investigations on the efficacy of butafosfan in the prevention of metabolic disorders in dairy cows in the peri-partal period. DVM Thesis. Justus-Liebig-University Giessen, Germany.

Simon, F. 1990. Study on stress reducing effect of butaphosphan in sheep. Unpublished internal report: Bayer Healthcare AG, Leverkusen. Bayer ID 12765.

Taoka, S., R. Padmakumar, M. Lai, H. Liu, and R. Banerjee. 1994. Inhibition of the human methylmalonyl-CoA mutase by various CoA esters. J. Biol. Chem. 269:31630-31634.

van Dorland, H. A., S. Richter, I. Morel, M. G. Doherr, N. Castro, and R. M. Bruckmaier. 2009. Variation in hepatic regulation of metabolism during the dry period and in early lactation in dairy cows. J. Dairy Sci. 92:1924-1940.

van Knegsel, A. T. M., H. van den Brand, J. Dijkstra, S. Tamminga, and B. Kemp. 2005. Effect of dietary energy source on energy balance, production, metabolic disorders and reproduction in lactating dairy cattle. Reprod. Nutr. Dev. 45:665-688. 